\title{
Camurati-Engelmann disease
}

\section{Neil Bellew, MB BCh, DA (SA), FCRad Diag (SA)}

Department of Radiology, Steve Biko Academic Hospital and Univerity of Pretoria

\section{Georg Wagener, MB ChB, BSc Hon (Biochem), MMed (Rad)}

Department of Radiology, Stellenbosch University

\section{Introduction}

Camurati-Engelmann disease (CED), or progressive diaphyseal dysplasia, is a rare sclerosing dysplasia of which 250 cases have been described in the English literature. ${ }^{1}$ The disease affects one in a million people and is autosomal dominant with variable penetrance. ${ }^{2-5}$ It was initially described by Cockayne in 1920; Camurati was the first to suggest its hereditary nature in $1922 .^{6-8}$ A single case of muscular wasting and marked bone involvement was reported by Engelmann in $1929 .{ }^{6,9}$ As the name suggests, there is progressive hyperostosis and predominant involvement of the diaphyses. ${ }^{6,10}$

The onset of the disease is usually during childhood; patients usually present by puberty and usually before age 30 , with limb pain, muscular weakness, waddling gait and easy fatigue. Other symptoms and signs may include delayed growth, reduced muscle mass, anorexia and enlargement of the arms and legs. ${ }^{6,11}$ Systemic manifestations of hepatosplenomegaly, bone marrow dysfunction (anaemia and leucopaenia) and delayed sexual development occasionally occur. ${ }^{4-6,12,13}$ In a few patients, abnormal values of bone resorption and formation have been described. ${ }^{10}$

Radiologically, the hallmark of the disorder is bilateral, symmetrical cortical thickening of the diaphyses of the long bones ${ }^{14,15}$ on both the

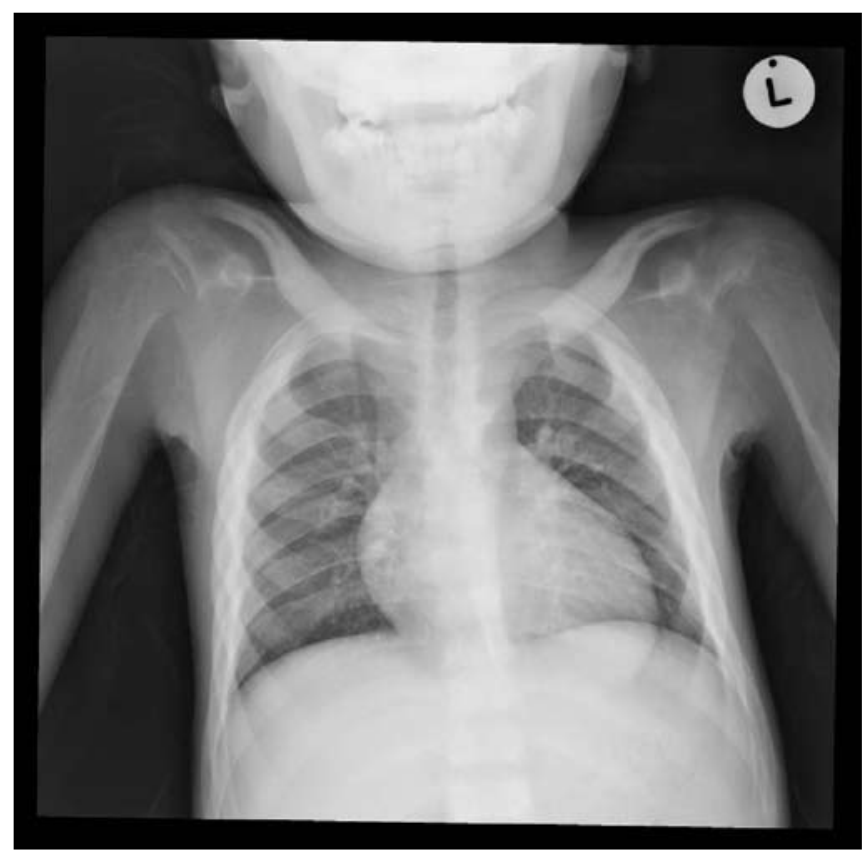

Fig. 1. Both clavicles demonstrate marked bony cortical thickening with sparing of the distal ends. The humeral epiphyses are spared. periosteal and endosteal sides of the diaphyses. In decreasing order of frequency, the tibia, femur, fibula, humerus, ulna and radius are affected. CED results from disturbance of intramembranous ossification (Fig.1) affecting the long bones, calvaria, mandible and facial

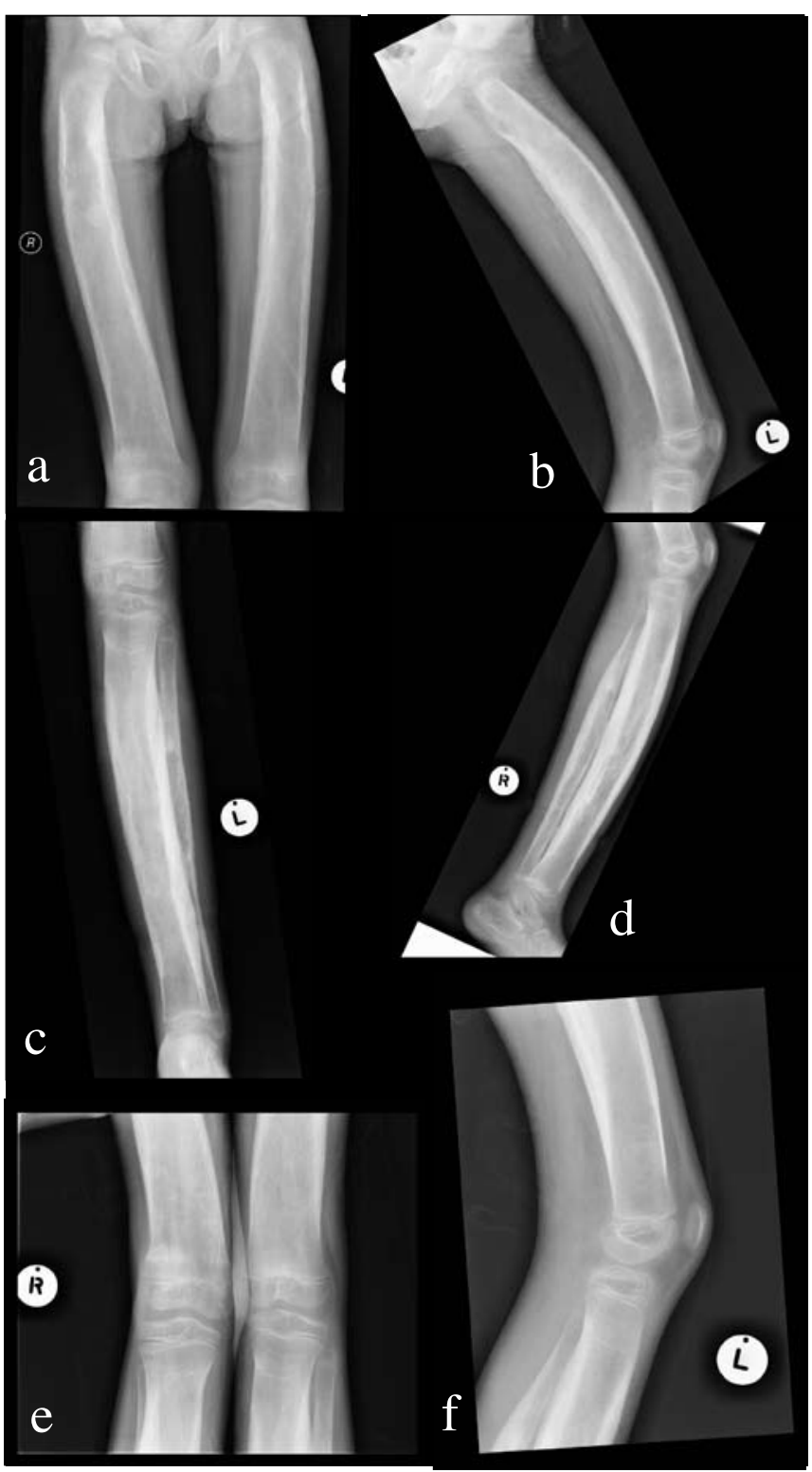

Figs $2 a-f$. The diaphyses of the long bones demonstrate endosteal and periosteal thickening with narrowing of the medullary cavity. Note the typical sparring of the epiphyses. 


\section{PICTORIAL ESSAY}
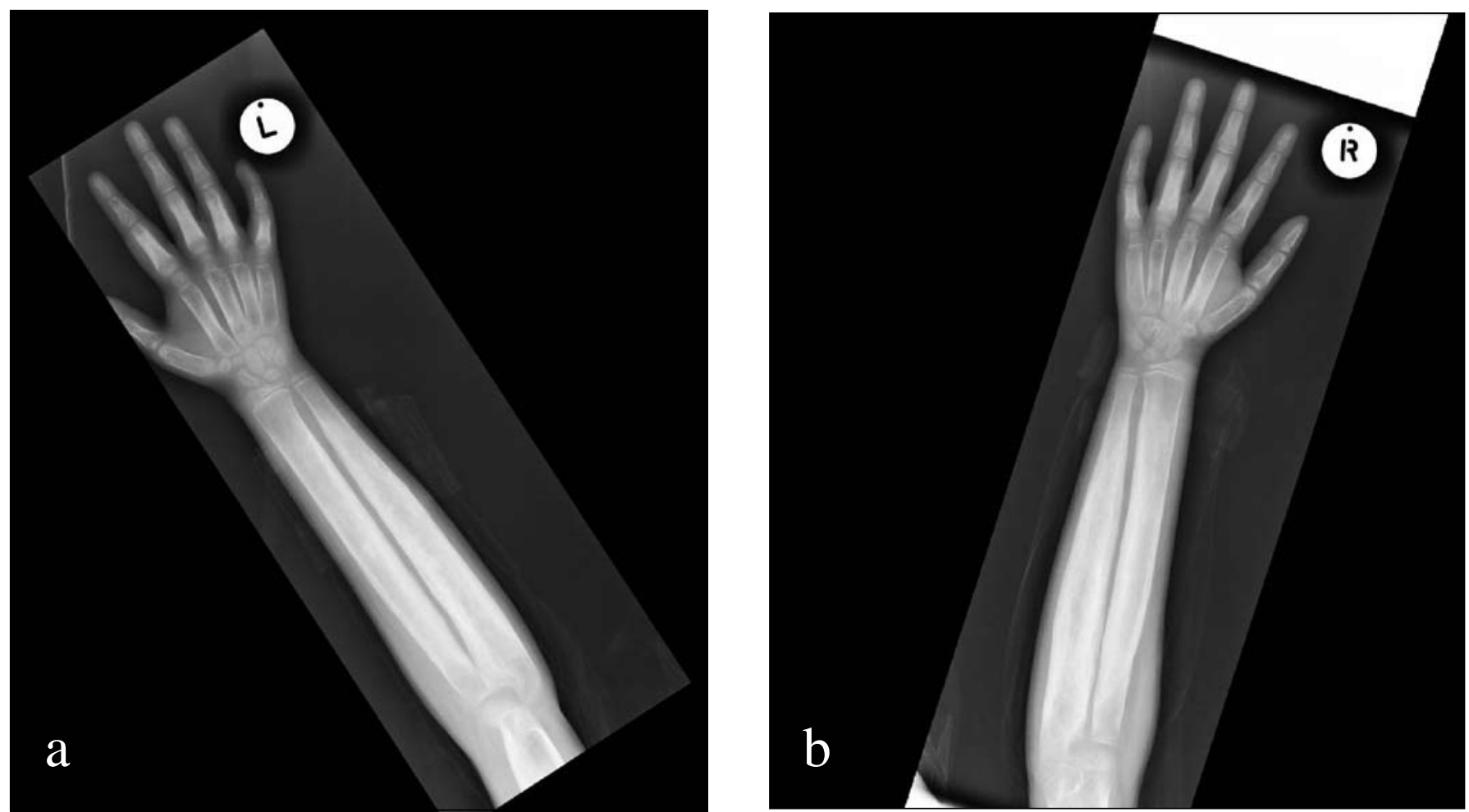

Figs $3 a$ and $b$. The marked cortical thickening results in narrowing of the medullary cavity.
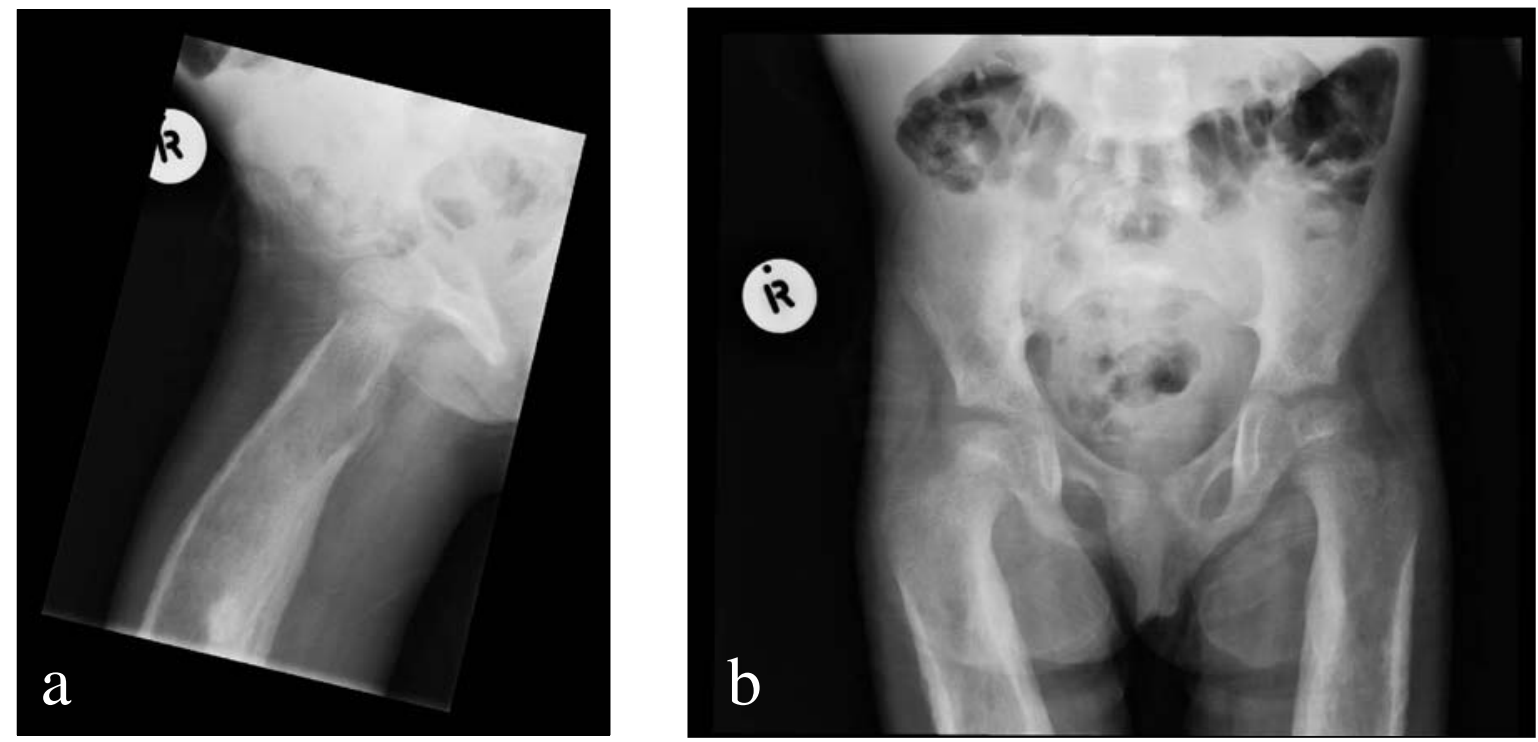

Figs $4 a$ and $b$. Classical sparing of the epiphysis and metaphysis of the proximal femora.

bones. ${ }^{11,16}$ There are a few reported cases of involvement of the skull base (a site of endochondral ossification), but these occur in advanced stages. ${ }^{3,11,17,18}$

\section{Radioclinical features}

According to a retrospective study of 24 families done by Janssens et al., ${ }^{6}$ clinical symptoms were documented in $74 \%$ of the patients. The most frequent clinical symptoms were pain in the extremities (63\%), easy fatigue (44\%), waddling gait (48\%), muscle weakness (39\%), reduced subcutaneous fat (21\%) and hearing loss (15\%).
Radiographically, endosteal and periosteal thickening of the diaphyses of long bones (Figs. 2a - f) is seen in CED., ${ }^{3,11,17,18}$ The result is narrowing of the medullary cavity (Figs 3a, b). The metaphyses can become affected, but typically the epiphyses are spared (Figs 4a, b) ${ }^{4,6}$ Sclerosis of the skull base (Figs $5 \mathrm{a}, \mathrm{b}$ ) can be present, leading to hearing impairment owing to progressive stenosis of the external auditory canal (EAC), and foraminal stenosis causing cranial nerve dysfunction. ${ }^{6,11,19}$

Increased osteoblastic activity detected scintigraphically with 99Tc-HMDP (hyfroxymethylene diphosphonate) is seen bilaterally symmetrical in the upper and lower limb long bones, longitudinally 


\section{PICTORIAL ESSAY}

Table I. Classification of dysplasias with increased bone density according to International Nomenclature and Classifications of the Osteochondrodysplasias (modified from Vanhoenacker FM et al. ${ }^{13}$ )

\begin{tabular}{|c|c|c|}
\hline Disorder & Radiological pattern of sclerosis & Mode of inheritance \\
\hline \multicolumn{3}{|c|}{ 1. Increased bone density without modification of bone shape } \\
\hline $\begin{array}{l}\text { Osteopetrosis } \\
\text { precocious type } \\
\text { delayed type } \\
\text { intermediate type } \\
\text { with renal tubular acidosis }\end{array}$ & $\begin{array}{l}\text { Generalised } \\
\text { Type } 1 \text { uniform } \\
\text { Type } 2 \text { endobones } \\
\text { Generalised } \\
\text { Similar other types }\end{array}$ & $\begin{array}{l}\text { AR } \\
\text { AD } \\
\text { AR } \\
\text { AR }\end{array}$ \\
\hline $\begin{array}{l}\text { Axial osteosclerosis } \\
\text { osteomesopyknosis } \\
\text { with bamboo hair }\end{array}$ & Focal sclerosis in vertebrae/pelvis & $\begin{array}{l}\mathrm{AD} \\
\mathrm{AR}\end{array}$ \\
\hline Pycnodysostosis & Generalised & AR \\
\hline Osteosclerosis Stanesu type & Cortical thickening of long bones, deficient facial sinus development & $\mathrm{AD}$ \\
\hline $\begin{array}{l}\text { Osteopathia striata } \\
\text { isolated } \\
\text { with cranial sclerosis }\end{array}$ & $\begin{array}{l}\text { Radiodense striations on all bones } \\
\text { with cranial sclerosis }\end{array}$ & $\begin{array}{l}\text { SP } \\
\text { XLD }\end{array}$ \\
\hline Sponastrime dysplasia & Striated metaphysis & $\mathrm{AR}$ \\
\hline Melorheostosis & Flowing hyperostosis & SP \\
\hline Osteopoikilosis & Radiodense spots & $\mathrm{AD}$ \\
\hline Mixed sclerosing bone dysplasia & Combined pattern & SP \\
\hline \multicolumn{3}{|c|}{ 2. Increased bone density with diaphyseal involvement } \\
\hline Diaphyseal dysplasia, Camurati-Engelmann & Craniotubular sclerosis, symmetrical & $\mathrm{AD}$ \\
\hline Craniodiaphyseal dysplasia & Craniotubular & $\mathrm{AR}, \mathrm{AD}$ \\
\hline Lenz Majewski dysplasia & Craniotubular & SP \\
\hline $\begin{array}{l}\text { Endosteal hyperostosis } \\
\text { van Buchem type } \\
\text { Worth type } \\
\text { sclerosteosis } \\
\text { with cerebellar hypoplasia }\end{array}$ & Craniotubular sclerosis, symmetrical & $\begin{array}{l}\mathrm{AR} \\
\mathrm{AD} \\
\mathrm{AR} \\
\mathrm{AR}\end{array}$ \\
\hline Kenny Caffey dysplasia & Diaphyseal cortex & $\mathrm{AD}, \mathrm{AR}$ \\
\hline Osteoectasia with hyperphosphatasia (juvenile Pagets) & Craniotubular sclerosis, bowing & AR \\
\hline Diaphyseal dysplasia with anaemia & Diaphyseal cortex & AR \\
\hline $\begin{array}{l}\text { Diaphyseal medullary stenosis with bone malignancy } \\
\text { (Hardcastle) }\end{array}$ & Diaphyseal cortex & $\mathrm{AD}$ \\
\hline \multicolumn{3}{|c|}{ 3. Increased bone density with metaphyseal involvement } \\
\hline Pyle dysplasia & Erlenmeyer & $\mathrm{AR}$ \\
\hline $\begin{array}{l}\text { Craniometaphyseal dysplasia } \\
\text { severe type } \\
\text { mild type } \\
\text { other type }\end{array}$ & Pyle-like, but cranial bones more affected & $\begin{array}{l}\mathrm{AR} \\
\mathrm{AD}\end{array}$ \\
\hline Frontometaphyseal dysplasia & Frontal bones & XLR \\
\hline Dysosteosclerosis & $\begin{array}{l}\text { Generalised } \\
\text { Platyspondyly }\end{array}$ & $\begin{array}{l}\text { AR } \\
\text { XLR }\end{array}$ \\
\hline Oculodento-osseous dysplasia & Craniotubular and mandible & $\mathrm{AD}$ \\
\hline Trichodento-osseous & Craniotubular & $\mathrm{AD}$ \\
\hline \multicolumn{3}{|c|}{ 4. Neonatal severe osteosclerotic dysplasia } \\
\hline Blomstrand & Generalised & AR \\
\hline Raine dysplasia & $\begin{array}{l}\text { Mild craniofacial sclerosis } \\
\text { Undermodelled long bones }\end{array}$ & ? \\
\hline Prenatal onset Caffey disease & Diaphyseal cortical thickening, bowed long bones & ?AR \\
\hline
\end{tabular}




\section{PICTORIAL ESSAY}
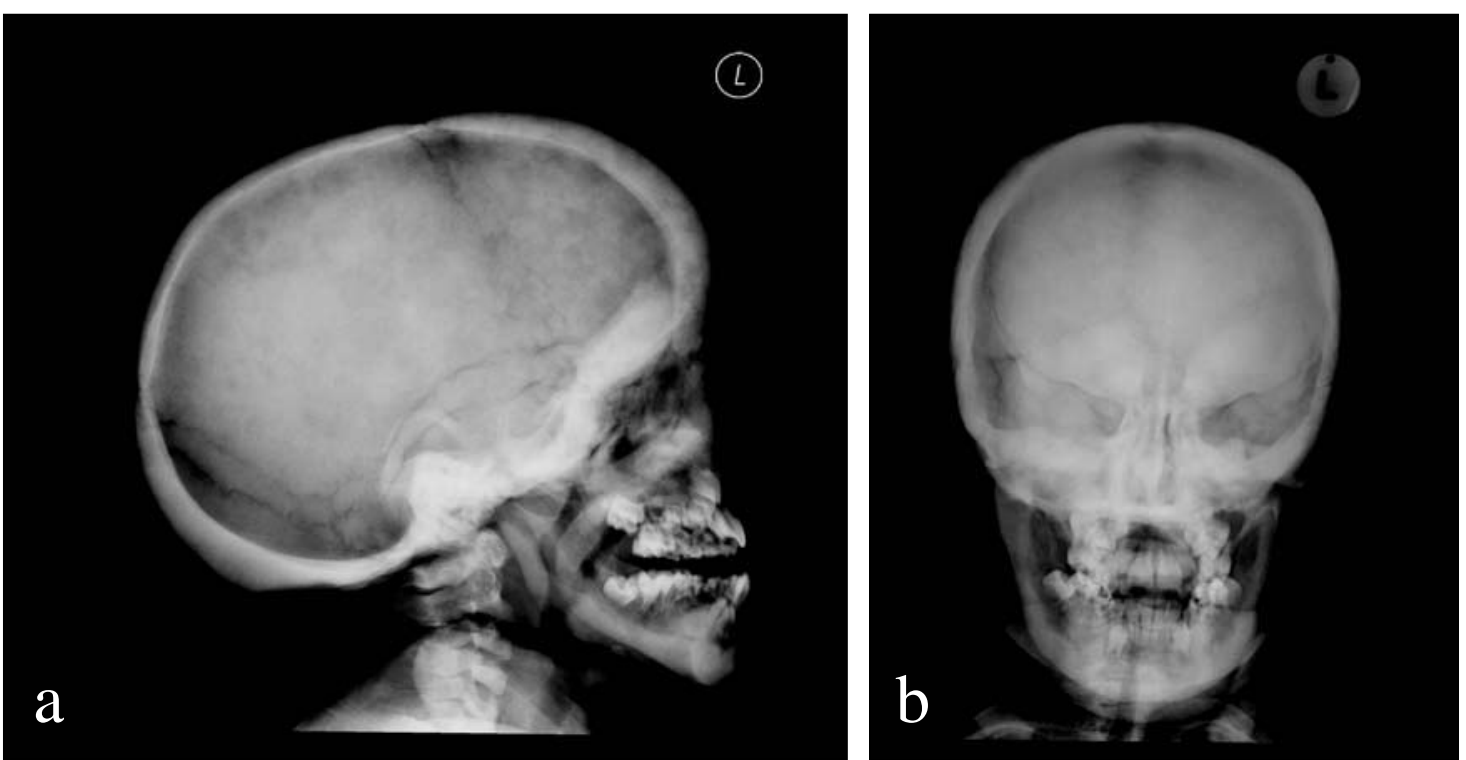

Figs $5 a$ and $b$. The skull radiographs demonstrate sclerosis of the skull base and temporal bone, particularly of the external auditory canal.

along the bone cortices. ${ }^{6,15}$ Before sclerosis is seen radiologically, increased tracer uptake can be seen and is thus valuable in the early diagnosis.

\section{Diagnosis}

Ten different mutations of the TGFB1 (transforming growth factor B1) were identified in an analysis of 46 CED families. ${ }^{620-27}$ The TGFB1 gene is located on the chromosomal region 19q13.1.4 All investigated mutations increase the activity of TGFB $1 .{ }^{6}$ Under physiological conditions, TGFB1 has been shown to suppress bone formation and the mutation stimulates bone formation 6 thus disrupting bone turnover, causing increased bone formation. TGFB1 also inhibits myogenesis, causing muscle wasting as well as lipogensis. ${ }^{6}$

CED is classified as a sclerosing bone dysplasia with diaphyseal involvement (Table I). The differential diagnosis is endosteal hyperostosis - van Buchem sclerosteosis, Kenny-Caffey disease or Worth type. Owing to inheritance, one can rule out van Buchem sclerosteosis (autosomal recessive (AR)), and Worth type is a more benign form and has associated mandible enlargement. ${ }^{4,13}$

A combination of clinical, radiological, scintigraphic and molecular data are mandatory for a definitive diagnosis.

\section{Treatment}

Immunosuppressive agents such as anti-inflammatories and glucocorticosteroids have the negative side-effect of decreasing bone density; and this is used in CED as treatment. The role of the agents is to increase the apoptosis rate of osteoblasts and osteocytes and at the same time to suppress osteoblast proliferation, differentiation and bone matrix synthesis. ${ }^{6}$ Further effects are to enhance proliferation and differentiation of osteoclast precursors ${ }^{6}$ and also to decrease intestinal calcium absorption. ${ }^{6}$ Glucocorticosteroids as well as counteracting bone formation exert a direct effect on TGFB expression. Prednisolone has been described as an effective treatment in a number of cases. ${ }^{6}$

Long-term treatment is not advisable owing to its unfavourable sideeffects such as impaired growth and spinal osteoporosis. A good starting dose is $1 \mathrm{mg} / \mathrm{kg} / \mathrm{day}$, but should be lowered in long-term treatment.
An alternative to medication is surgery. Reaming of the medullary cavity may be done to decrease the narrowing of the canal, or an osteotomy can be performed. ${ }^{6,28}$ Further decompression in optic nerve compression has also been done. Gene therapy is a possibility in the future.

\section{Conclusion}

Camurati-Engelmann disease (CED), or progressive diaphyseal dysplasia, is a rare sclerosing dysplasia whose onset is usually during childhood. Patients usually present by puberty or before age 30 . Radiologically, the hallmark of the disorder is bilateral, symmetrical cortical thickening of the diaphyses of the long bones occuring on both the periosteal and endosteal sides of the diaphyses.

The differential diagnosis is of CED is endosteal hyperostosis van Buchem, sclerosteosis, Kenny-Caffey disease and Worth type. Inheritance can rule out van Buchem and sclerosteosis (AR), whereas Worth type is a more benign form and has associated mandible enlargement. A combination of clinical, radiological, scintigraphic and molecular data may be necessary for a definitive diagnosis.

1. Brat HG, Hamoir X, Matthijs P, et al. Camurati-Engelmann disease: A late and sporadic case with metaphyseal involvement. Eur Radiol 1999;9:159-162.

2. Wynne-Davies R, Hall CM, Apley AG. Engelmann’s disease. In: Wynne-Davies R, ed. Atlas of Skeletal Dysplasias. Edinburgh: Churchill Livingstone 1985:488

3. Vanhoenacker FM, Janssens K, van Hul W, et al. Camurati-Engelmann disease: review of radioclinical features. Acta Radiologica 2003;44(4):430-434.

4. Simsek S, Janssens K, Kwee ML, et al. Camurati-Engelmann disease (progressive diaphyseal dysplasia) in a Moroccan family. Osteoporosis Int 2005;16:1167-1170.

5. Whyte MP. Primer on the metabolic bone diseases and disorders of mineral metabolism, sect VIII Genetic, Developmental, and Dysplastic Skeletal Disorders, 5th ed. Washington, DC: American Society for Bone and Mineral Research, 2003:449-478.

6. Janssens K, Vanhoenacker F, Bonduelle M, et al. Camurati-Engelmann disease: review of the clinical, radiological, and molecular data of 24 families and implications for diagnosis and treatment. J Med Genet 2006;43:1-11.

7. Cockayne EA. Case for diagnosis. Proc R Soc Med 1920;13:132-136.

8. Camurati M. Di un raro caso di osteite simmetrica ereditaria degli arti inferiori. Chirurgia degli Organi di Movimento 1922;6:662-665.

9. Engelmann G. Ein fall von ostheopathia hyperostotica (sclerotisans) multiplex infantilis. Forschritte auf dem Gebiete der Rontgenstrahlen und der Nuklearmedizin 1929;39:1101-1106.

10. Smith R, Walton RJ, Corner BD, Gordon IR. Clinical and biochemical studies in Engelmann's diseas (progressive diaphyseal dysplasia). QJM 1977;46:273-294. 
11. Stasolla A, Magliulo G, Bellussi A, et al. Imaging of the temporal bone in Camurati- Engelmann dysplasia with an 11-year follow-up. Otology \& Neurology. 2005;26:773-777.

12. Crisp AJ, Brenton DP. Engelmann's disease of bone - a systemic disorder? Ann Rheum Dis 1982;41:183188.

13. Vanhoenacker FM, De Beuckeleer LH, van Hul W, et al. Sclerosing bone dysplasias: genetic and radioclinical features. Eur Radiol. 2000;10:1423-1433.

14. Rimoin DL. International nomenclature of constitutional diseases of bone. J Pediat 1978;93:614-616.

15. Momose M, Yoshida K, Yanagisawa S, et al. Camurati-Engelmann disease on a 99mTc-HMDP bone scan. Eur J Nucl Med Mol Imaging 2008;35:214.

16. Greenspan A. Sclerosing bone dysplasias: A target-site approach. Skeletal Radiol 1991;20:561-583.

17. Vanhoenacker FM, DeBeuckeleer LH, Van Hul W, et al. Sclerosing bone dysplasias: Genetic and radioclinical features. Eur Radiol 2000;10:1423-1433.

18. Kaftori JK, Kleinhaus U, Naveh Y. Progressive diaphyseal dysplasia (Camurati-Engelmann): Radiographic follow-up and CT findings. Radiology 1987;164:777-782.

19. Cheung SW, Jackler RK. Diffuse osseous lesions of the temporal bone. In: Jackler RK, Brackmann DE, eds. Neurotology. St. Louis: Mosby Year Book, 1994:1 189-1202.

20. Campos-Xavier B, Saraiva JM, Savarirayan R, et al. Phenotypic variability at the TGFbetal locus in Camurati-Engelmann disease. Hum Genet 2001;109:653-658

21. Wallace SE, Lachman RS, Mekikian PB, Bui KK, Wilcox WR. Marked phenotypic variability in progressive diaphyseal dysplasia (Camurati-Engelmann disease): report of a four-generation pedigree, identification of a mutation in TGFB1, and review. Am J Med Genet 2004;129A:235-247.
22. Janssens K, Gershoni-Baruch R, Guanabens N, et al. Mutations in the gene encoding the latency-associated peptide of TGF-beta 1 cause Camurati-Engelmann disease. Nat Genet 2000;26:273-275.

23. Kinoshita A, Saito T, Tomita H, et al. Domain-specific mutations in TGFB1 result in Camurati-Engelmann disease. Nat Genet 2000;26:19,20.

24. Hecht JT, Blanton SH, Broussard S, Scott A, Rhoades Hall C, Milunsky JM. Evidence for locus heterogeneity in the Camurati-Engelmann (DPD1) syndrome. Clin Genet 2001;59:198-200.

25. Mumm SR, Obrecht S, Podgornik MN, Whyte MP. Camurati-Engelmann Disease: New mutations in the latency-associated peptide of the transforming growth factor beta-1 gene. J Bone Miner Res 2001;16(suppl 1):S223.

26. Janssens K, ten Dijke P, Ralston SH, Bergmann C, Van Hul W. Transforming growth factor-beta 1 mutations in Camurati-Engelmann disease lead to increased signaling by altering either activation or secretion of the mutant protein. J Biol Chem 2003;278:7718-7724.

27. Kinoshita A, Fukumaki Y, Shirahama S, et al. TGFB1 mutations in four new families with CamuratiEngelmann disease: confirmation of independently arising LAP-domain-specific mutations. Am J Med Genet 2004;127A:104-107.

28. Raffaelli P, Ronzini MF. Camurati-Engelmann's disease. A case report. Ital J Orthop Traumatol $1988 ; 14: 267-271$

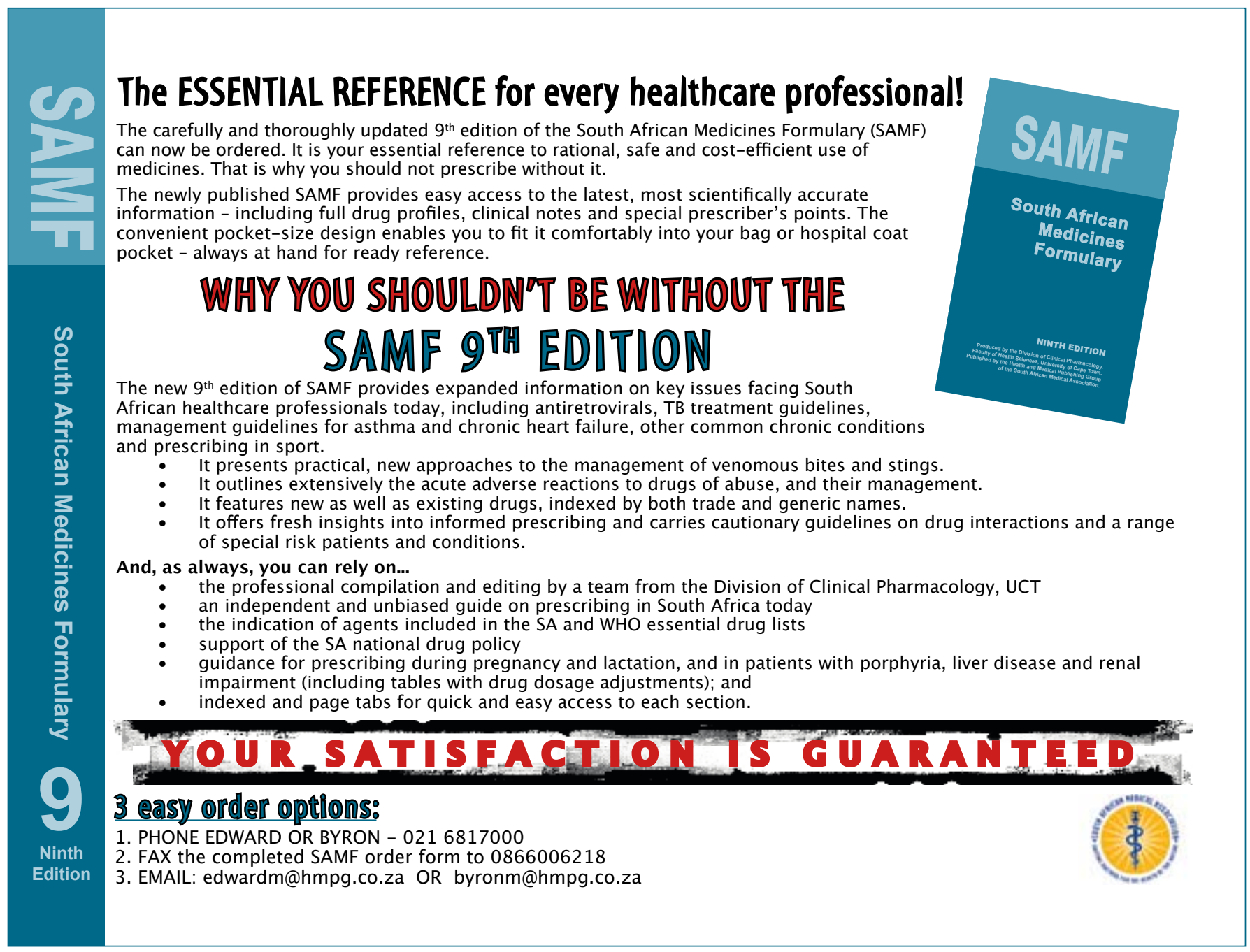

